\title{
7 THE COMMON DENOMINATOR. ROMANIA AND THE NORDIC COUNTRIES, 1966-1969
}

\section{Cezar Stanciu}

Valahia University of Târgoviște, „Grigore Gafencu” Center for the History of International Relations and Cultural Studies, E-mail: cezar.stanciu@centrulgafencu.ro

\section{Acknowledgments}

The article is based on a paper presented at the Second International Conference of the Romanian Association for Baltic and Nordic Studies: Black Sea and Baltic Sea Regions: Confluences, influences and crosscurrents in the modern and contemporary ages, at Târgovişte, May 20-22, 2011.

\begin{abstract}
:
One of Nicolae Ceauşescu's beliefs was that international security and cooperation could not rely on Cold War bipolarity, but on active involvement from every state in promoting its interests and points of view. In defending such policies, Romania sought not only to affirm its sovereignty in front of Moscow, but also to build bridges towards other countries sharing similar ideas. Starting from the early 1960s, Romania developed a coherent policy towards Nordic Europe, consisting in both economic and political cooperation. The neutrality of countries such as Sweden or Finland was regarded in Bucharest as directed against superpowers bipolarity which served as a common denominator. This paper deals with Romania's relations in Nordic Europe during the 1960s, investigating the rationalities and factors which contributed to the emergence of constructive cooperation among countries with such different backgrounds.
\end{abstract}

\section{Rezumat:}

Una dintre convingerile lui Nicolae Ceauşescu era că securitatea şi cooperarea internațională nu se puteau baza pe bipolaritatea războiului rece ci pe implicarea activă a tuturor statelor în promovarea propriilor interese şi puncte de vedere. România căuta în acest fel să-şi afirme independența față de Moscova şi să construiască punți către alte state care îi împărtăşeau viziunea. Începând cu anii 1960, România a dezvoltat o politică tot mai coerentă față de Europa Nordică, bazată pe cooperare politică şi economică. Neutralitatea unor țări ca Suedia sau Finlanda era 
văzută la Bucureşti ca fiind îndreptată împotriva bipolarității şi aceasta a servit ca numitor comun. Această lucrare tratează relațiile României în Europa Nordică în anii 1960, investigând rațiunile şi factorii care au contribuit la dezvoltarea unor relații constructive între țări care aveau atât de puține în comun.

Keywords: Romania, Nordic Europe, Cold War, economic cooperation, neutrality, small states, state visits

In the fall of 1960, a Romanian governmental delegation led by Mihail Florescu visited Scandinavia, looking for business opportunities in the North ${ }^{1}$. It was the first such visit after World War II and it marked a very successful opening in Romania's relations with the Northern countries, as the future would prove. As it relies on Romanian archival sources, this study will focus on Romania's policy towards Scandinavia and will reveal, form this point of view, the rationalities behind the political congruencies which allowed a rather strong political rapprochement in the late 1960s. This statement is valid mostly for Romania's relations with Finland and Sweden, in spite of the fact that there were no special traditions nor interests for intense relations between medium countries form the Balkans and Scandinavia. Neither one of these countries had pursued a particular course of rapprochement towards the others, but it was rather the coincidence of interests favoured by the Cold War dichotomies which created links and connections where there previously were none.

In 1965, the United Nations voted a resolution with a very long and complicated title: "Actions on the regional level with a view to improving good neighbourly relations among European states having different social and political systems". The most interesting part of that resolution was not its text, but its intentions - it was initiated and promoted by a group of nine countries: Romania, Bulgaria and Hungary/ Austria, Finland and Yugoslavia/ Belgium, Denmark and Sweden². As this list shows, it was a peace and

1 Cezar Stanciu, "Scandinavian Perspectives. Overcoming the Cold War pressures in Romania's policy towards Northern Europe". Revista Română de Studii Nordice şi Baltice, 1 (2009): 51-62.

2 Annual Report of the Secretary-General on the Work of the Organization (United Nations, 1965), 45 
cooperation initiative concerning East-West relations which did not include any of the Great Powers ${ }^{3}$. It was for the first time in divided Europe when small countries belonging to both military blocs decided to ignore both Moscow and Washington and make a step - as small as it may had been towards an improvement in political and economic cooperation, towards overcoming the climate of mistrust ${ }^{4}$.

Practically, small states of Europe, on both sides of the Iron Curtain, were claiming their right to have a saying in their future. It was exactly the kind of attitude which facilitated the Romanian-Scandinavian relations mentioned above. The resolution was initially proposed by Romania in 1960 but, in order to ensure its success, Romanian Foreign Minister Corneliu Mănescu and his deputy Mircea Malița decided to adopt other countries as initiators, as well. The Resolution ambitiously stated that the group of nine countries was interested in a "transformation of the European international system away from inter-bloc relations to pluralized, inter-national relations in which all states, in principle, should participate equally" 5 . The development of Romanian - Scandinavian relations was practically a materialization of this generous aim.

The 1960s were a favourable framework for the political affirmation of small states all over the world, as the Americans and the Soviets were becoming more and more tired by their superpower responsibilities. Also, along with the de-colonization, starting from the mid fifties a new political current was gaining momentum on the international scene: the nonalignment movement ${ }^{6}$. One of the key features of the non-aligned rhetoric was rejecting Great Power politics, the alignment to one or the other of the two military blocs. This was also a major component of the abovementioned Resolution, even if it was far from being a manifestation of nonalignment. What the Resolution had in common with non-alignment, actually, was the affirmation of small states in a world dominated by Great

\footnotetext{
${ }^{3}$ Mircea Malița, Tablouri din războiul rece. Memorii ale unui diplomat român (Bucureşti: Editura C.H. Beck, 2007), 103

4 Janie Leatherman, From Cold War to democratic peace: third parties, peaceful change, and the OSCE (New York: Syracuse University Press, 2003), 71

${ }^{5}$ Ibid.

6 U. S. Bajpai, Non-alignment, perspectives and prospects (Lancers Publishers, 1983), 105-106
} 
Powers 7 . The small states, as stated previously, were claiming their right to having a say in the world, even if they were aligned to a bloc or not.

Finland was a major example from this point of view. Having to survive as a democratic and capitalist country in the immediate vicinity of the Soviet Union was a terrible challenge for the post-war Finnish policymakers $^{8}$. The obvious prime option would have been membership in the western bloc, but the Finns understood that, while the Americans were very far, the Soviets were, on the other hand, very close. They had the chance to experience that in the Winter War. Finland chose to rely only on itself in pursuing security and decided to do that by maintaining close relations with the USSR and refusing NATO membership as well as any other gesture which might had been interpreted as aggressive by the Soviets9. This involved a dangerous game in which Moscow had to be reassured at all times that Finland had friendly intentions, that it was a reliable partner, and at the same time, preserving the country's independence and identity. The accomplishment of this dangerous game came to be known as the Paasikivi-Kekkonen line ${ }^{10}$. The ultimate purpose of the policy was, after all, to preserve a small state's sovereignty under the pressure of a Great Power.

Sweden had a much easier situation. It was neutral in both World Wars and also remained neutral in the Cold War, but it had favourable circumstances due to its geographical position ${ }^{11}$. Still, Sweden played a very important role in the Cold War especially by emphasizing the importance of cooperation. Its diplomacy pursued with relentless energy peace and cooperation not only in the north, but also in the entire world, and Swedish diplomats became known for their allegiance to principles of mutual respect and legalism in international relations. Sweden was a key factor in promoting what was later called non-alignment, but also in the

\footnotetext{
7 For a definition of small states and a general characterization of their foreign policies, see: Jeanne A. K. Hey, Small states in world politics: explaining foreign policy behavior (Lynne Rienner Publishers, 2003), 2-6

8 Raimo Väyrynen, Stability and change in Finnish foreign policy (Helsingin yliopiston, 1986), 910

9 Silviu Miloiu, O istorie a Europei nordice şi baltice, vol. II De la războiul rece la era globalizării (Târgovişte: Editura Cetatea de Scaun, 2005), 190-191

10 Christopher S. Browning, Constructivism, Narrative and Foreign Policy Analysis: A Case Study of Finland (Bern: Peter Lang, 2008), 205

11 Stig Hadenius, Swedish politics during the 20th century: conflict and consensus (Svenska institutet, 1997), 70-72

198
} 
development of regional cooperation, not only as a practical matter, but also as a theoretical issue ${ }^{12}$. Its devotion to developing the North as an area of security and institutionalized cooperation was an example for many other countries and offered a model for non-aligned behaviour in international relations. Its neighbours, Denmark and Norway, decided to join NATO but that was not an obstacle in creating the Nordic Council in 1952, bringing together the two Nordic NATO members and neutral Sweden ${ }^{13}$. In order to ensure its security, Sweden even decided in the mid 1960s to pursue an independent atomic program, but it finally gave it up in 1968, when the country signed the Treaty of Nuclear Non-proliferation.

Romania, on the other hand, was more suitable for a comparison with Denmark or Norway, from the point of view of military alignment. Still, this paper will focus on a comparison with Sweden and Finland, for reasons explained below. The Communist regime in Romania was known for a long time as one of the most subordinated among the satellites and Khrushchev even considered Romanian party leader Gheorghiu-Dej as one of his most faithful supporters in the circumstances of the Hungarian crisis of 1956. But during the troubled fifties, things were rarely what they appeared to be.

In the aftermath of Stalin's death, the changes in the Soviet leadership had caused great distress to the Romanian Communists, as the fight for power in Kremlin had a tendency to reverberate in the peoples' democracies ${ }^{14}$. Malenkov initiated a New Course which denied most of the Stalinist principles of industrialization and, later on, Khrushchev began replacing some of the party leaders in Eastern Europe, in an attempt to place his own men in key positions and consolidate his control ${ }^{15}$. For Gheorghiu-Dej this was a tremendous threat to his position, shortly after he had just won a decisive battle for power against the Pauker group, in 1952. In this situation, Gheorghiu-Dej chose caution and, as de-Stalinization

\footnotetext{
12 Nils Bertel Einar Andrén, Power-balance and non-alignment: a perspective on Swedish foreign policy (Almqvist \& Wiksell, 1967), 120-121

13 Erik Solem, The Nordic Council and Scandinavian integration (Praeger Publishers, 1977), 3639.

14 János Rainer, The New Course in Hungary in 1953. Working Paper nr. 38 (Woodrow Wilson International Center for Scholars, Washington, 2002), 14-15

${ }^{15}$ Mark Kramer, „The Early Post-Stalin Succession Struggle and Upheavals in East-Central Europe. Internal and External Linkages in Soviet Policy Making (Part I)". Journal of Cold War Studies I, no. 1 (1999), 7-10
} 
continued on with the Secret Report, he tried to elude the reforms, imitate the changes and trick the Soviets into believing that he was most suitable to serve their needs in Romania16.

At the same time, he started taking decisive, although discreet measures, to consolidate his regime, both domestically and externally. Gheorghiu-Dej's realization of the fact that subordination to Moscow was a threat to his position was a key factor in explaining Romania's future evolution in the Socialist camp. Gheorghiu-Dej pursued a policy aimed at strengthening his regime so as to reduce vulnerability in front of Soviet pressure. Domestically, this involved an improvement in the regime's relations with the society, by increasing the standard of living and reducing repression ${ }^{17}$. Abroad, the regime tried to improve the country's visibility and relations in the West, in order to be able to find alternative sources of funding and trade. Both domestically and externally, the main focus of this consolidation strategy was continuing and expanding the ambitious program of industrial development, as Romania was still one of the least developed countries in the Socialist camp. Gheorghiu-Dej successfully implemented this course without raising any Soviet suspicion until 1962, when the Soviet plans for Eastern Europe crashed with the Romanian plan for industrialization.

In 1962, at a CMEA meeting, Khrushchev enounced the famous Principle of Specialization as a potential base for the economic cooperation inside CMEA, in an attempt to intensify cooperation and integration in Eastern Europe, in a way inspired by the Common Market experience ${ }^{18}$. For Romania, Khrushchev's plans involved reducing investments in industry, in favour of agriculture. It was, after all, what the more industrialized countries of CMEA wished for. Gheorghiu-Dej would not accept this because it practically sabotaged his entire strategy. Moreover, he chose to reject the plan publicly, so as to compromise it completely, even though it was a very dangerous initiative. A public crash with the Soviets involved a

\footnotetext{
16 Dan Cătănuş, „Impactul raportului „secret” asupra conducerii PMR. Destalinizarea în România". Lagărul comunist sub impactul destalinizării. 1956, eds. Dan Cătănuş and Vasile Buga, (Bucureşti: Institutul Național pentru Studiul Totalitarismului, 2006), 114-120

17 Robert Forst, "Nicolae Ceauşescu, the "Great Genius of the Carpathians»", Balkan strongmen: dictators and authoritarian rulers of South Eastern Europe, ed. Bernd Jürgen Fischer (Purdue University Press, 2007), 319

18 Adam Zwass, The Council for Mutual Economic Assistance: the thorny path from political to economic integration (M.E. Sharpe, 1989), 33-34 
political component aimed at offering consistency and a theoretical background to such a position. At the same time, an ideological back-up would have kept the Romanian party away from accusations like deviation.

Gheorghiu-Dej pursued very boldly a course of public crash with Moscow especially because it benefited from favourable circumstances in the international Communist movement: the Sino-Soviet polemic and schism. After opposing the adoption of the Principle of Specialization by CMEA to Khrushchev's terrible surprise, Romania stubbornly refused any conciliation with Moscow and moreover engaged on a noisy course of political opposition, posing as a mediator in the Sino-Soviet polemic ${ }^{19}$. The ideological content of this opposition was openly expressed in the Declaration of 1964, which denied Moscow's role as leader of the Communist movement in favour of a multi-polar world of Communism ${ }^{20}$. In other words, the Declaration of 1964 claimed that each party had the right to decide its own domestic policy according to local and national specificity, which had a lot of the Titoist critique of the USSR, but it also claimed that relations between Communist parties should be governed by mutual respect and non-interference, which also borrowed some of the Chinese criticism of Great Power Chauvinism, addressed to the USSR.

Arguing each country's right to decide its own future, the document practically tried to avoid both Titoism and Maoism and incline towards the non-alignment rhetoric, which was ideologically convenient and kept Gheorghiu-Dej away from accusations of deviation. After his death in 1965, his successor Nicolae Ceauşescu continued this course with a lot of courage. Externally, this involved a very interesting evolution in foreign policy, aimed at improving relations with both China and the Western countries, in order to counterbalance the Soviet Union. Especially in what regarded the economic pressures and dependencies involved by the previous relations with Moscow, Romania paid great attention to identifying new potential markets and partners in the West. From this point of view, Scandinavia was a region with great possibilities for

\footnotetext{
19 Vladimir Tismăneanu, Stalinism for all seasons: a political history of Romanian communism (University of California Press, 2003), 179. About the content of CMEA reforms, see: Jozef M. van Brabant, Socialist economic integration: aspects of contemporary economic problems in Eastern Europe (Cambridge University Press, 1980).

${ }^{20}$ Dragoş Petrescu, ,Legitimacy, Nation-Building and Closure: Meanings and Consequences of the Romanian August of 1968", in The Prague Spring and the Warsaw Pact Invasion of Czechoslovakia, 1968, ed. M. Mark Stolarik (Bolchazy-Carducci Publishers, 2010), 239.
} 
business, also supported by these countries' neutrality, which involved fewer obstacles in developing economic cooperation.

In February 1966, Romanian Ministry of Foreign Affairs conveyed a note to the Central Committee of the RCP (Romanian Communist Party) in which it proposed an exchange of visits of prime-ministers between Romania, on one hand, and Finland and Sweden, on the other hand ${ }^{21}$. The note made a short but comprehensive analysis of Romania's relations with these countries, noticing their growing interest for developing bilateral relations. The note justified the recommendation offering four main arguments: the possibility to develop trade relations with Nordic countries, their scientific advance which opened the way for technological cooperation, their allegiance to neutrality and - last but not least - the possibility to expand Nordic tourism to Romania ${ }^{22}$. These arguments offer a clear view on Romania's interests in foreign policy.

The conditions for such progress seemed to be ripped in the fall of 1966, at least when it comes to Romanian-Swedish relations. Both parts were willing to speak and interested to listen. Swedish Ambassador in Bucharest, Olof Bjurström was informing Romanian Ministry of Foreign Affairs in September that Swedish Foreign Minister Torsten Nilsson was willing to visit Romania sometime next year, on which occasion he was empowered to bring an invitation to Sweden addressed to Romanian premier I.Gh. Maurer ${ }^{23}$. Also, towards the end of 1966 similar signals were being received from Norway, too. A Norwegian governmental commission had a meeting at the Romanian Economic Agency in Oslo, in an attempt to identify new ways of increasing mutual trade. The Norwegian government presented two proposals: an exchange of visits from economic delegations of the two countries, as well as a special visit from the Minister of Industry in Norway to Romania, a plan of which the official was very fond. The recommendation made by the Economic Agency in Oslo was to accept both suggestions ${ }^{24}$.

\footnotetext{
${ }^{21}$ Notă de propuneri referitor: organizarea unui schimb de vizite la nivelul şefilor de guverne între Republica Socialsită România şi țările nordice, in ANIC, fund CC al PCR - secția Cancelarie, dossier no. 19/1966, 20

22 ibid., 23

${ }^{23}$ Notă de propuneri referitor: schimb de vizite oficiale între Suedia şi Republica Socialistă România, in ANIC, fund CC al PCR - sectia Cancelarie, dossier no. 128/1966, 17

24 Notă referitor: propunerea norvegiană de organizare a unui schimb de delegații economice în anul 1967, in ANIC, fund CC al PCR - secția Cancelarie, dossier no. 48/1967, 20-21

202
} 
Romania's trade with Norway was well beneath the possibilities, although the political restrictions were much lower. This was due mainly to geographical distance, as the Agency's analysis revealed, but developing trade was strongly encouraged by the Romanian specialists in Oslo especially because they noticed large possibilities for exporting industrial products from chemistry or machine building in this country ${ }^{25}$. Romania was keen on overcoming the status of an underdeveloped country and the large investments made in heavy industry during Stalin's time and after paid off, as Romania's industrial output continued to increase a great deal. This evolution, combined with Bucharest's more and more independent voice in foreign relations, made Romania an interesting case for the West and Nicolae Ceauşescu knew how to take advantage of this.

In what concerned the North, Romania often found itself on similar positions with one or the other of these countries, as it resulted clearly in February 1967, when Finish Foreign Minister Ahti Karjalainen visited Bucharest. Karjalainen had meetings with his homologous Corneliu Mănescu and discussed the status of Romanian-Finnish relations, economically and politically. On 17 February 1967 Karjalainen met with Ceauşescu to discuss general matters of foreign policy. First of all, both officials expressed without any doubt their government's dedication to improving bilateral relations and their commitment to peace and cooperation in the spirit of the UN Resolution mentioned above. Karjalainen told Ceauşescu: "we consider that collaboration between our countries which is not directed against any state, but directed towards solving some of the first rank international problems, can be and we think that it must be continued." 26 In his opinion, Romania and Finland had common points of view on key issues and he also declared Finland's sympathy for the Romanian efforts to develop and industrialize.

Ceauşescu gave a very clear expression of these common points of view, when referring to Romania's goals in foreign policy: "we agree that big countries have larger responsibilities and possibilities, but we don't think it's wise to leave only these countries to solve problems which concern collaboration among nations and ensuring peace. We believe that it's necessary for each state to

\footnotetext{
25 ibid., 21

26 Stenograma discuțiilor avute cu ocazia primirii de către tovarăşul Nicolae Ceauşescu a ministrului Afacerilor Externe al Finlandei, Ahti Karjalainen, în ziua de 17 februarie 1967, in ANIC, fund CC al PCR - secția Relații Externe, dossier no. 8/1967, 3
} 
participate in finding the best solutions to the problems which preoccupies the whole world." 27 Ceaussescu spoke of a situation familiar to the Finns, due to their geography. He told Karjalainen plainly, as if he was trying to convey a message to Helsinki: "if some states renounce their sovereign role, renounce their contribution to solving problems, giving the natural responsibility of that state in others' hands, of course that this will not create favourable conditions for developing cooperation and security." 28 Ceauşescu was saying practically the same thing his propaganda said, but in other words: Romania will not accept anyone speaking on its behalf, not even the Soviet Union.

After this ambitious statements, Ceauşescu and Karjalainen exchanged opinions about West Germany and Vietnam. Ceauşescu explained his Finnish guest that in his opinion it was very important to encourage those particular political forces in Bonn which favoured agreement and cooperation, but the Finish Foreign Minister maintained his opinion, that Finland should stay out of this issue and not recognize any of the two German states. For Helsinki, as Karjalainen pointed, it was not important to have diplomatic relations, but to have economic cooperation and commercial exchanges ${ }^{29}$. Economy, believed Karjalainen, was the most important mediator. In any case, the position was similar: Romania was the only Socialist country in Europe (except from the USSR) to recognize both German states, while Finland did not recognize any of them. It was an implicit denial of Bloc policy, of Cold War dichotomies forcing every country to take sides.

The next big step in Romanian-Finnish relations was premier Maurer's visit to Helsinki, in April 196830. It was the first stop of a longer visit to Scandinavia which included Sweden as well. Maurer was accompanied by Romanian Foreign Minister Corneliu Mănescu and spent nearly a week in Finland, having a very busy schedule which involved various meetings with Finnish officials and politicians, including President Urho Kekkonen, to whom Maurer offered an invitation to Romania. As a general feature of foreign policy, Finland had good relations with mostly all Socialist countries, due to the special nature of its relation to Moscow ${ }^{31}$.

\footnotetext{
27 ibid., 4

28 ibid., 5

29 ibid.

30 Scânteia, 1 aprilie 1968

31 For a political biography of President Urho Kekkonen, see: Keijo Korhonen, Urho Kekkonen: a statesman for peace (Helsinki: Otava, 1975).
}

204 
Romania, on the other hand, was a different case, firstly because it seemed so quiet for so long, it seemed to be the perfect satellite along with Bulgaria. Further more, its rupture with the Soviets was very noisy and accompanied by many spectacular gestures, as one that Maurer also did in Helsinki. For these reasons and not only, the Romanian delegation was surrounded by a lot of attention by politicians, businessmen and media.

Concerning the kind of spectacular gestures mentioned above, it had already became a source of folklore among Romanian historians Maurer's courageous gesture of paying his respects at Marshall Mannerheim's monument. For Soviets, as well as for other Eastern European Communists, Mannerheim was a taboo: he was a hero of an antiSoviet war which the Soviets could not ban, like they did with Ion Antonescu. So they just kept quiet about it and tried to ignore the situation. During his visit to Helsinki, Maurer stopped at Mannerheim's monument in the city centre and kept a moment of recollection. This was considered extremely offensive by the Soviets, as they openly said it on various channels. For a long time, it was unknown whether this actually happened or it was a deliberate gesture, decided at home, or not. Recent declassified documents from the RCP archives show that it was not accidental. Maurer's directives discussed in the Central Committee Presidium and approved as such, under Ceauşescu's personal signature included the visit to Mannerheim's monument. A Note of recommendations issued by the Romanian Foreign Ministry and addressed to the party leadership included this as a proposal, which the Presidium approved ${ }^{32}$. The arguments put forth by the Ministry of Foreign Affairs were two: first, most foreign guests do that (but it "forgot" to say that only foreign guests from the West) and second, that President Tito of Yugoslavia did the same when he visited Helsinki (but Tito himself was an exception).

\footnotetext{
32 Notă de propuneri referitor: directive privind vizita în Finlanda a preşedintelui Consiliului de Miniştri, Ion Gheorghe Maurer, şi a ministrului afacerilor externe, Corneliu Mănescu (31 martie - 5 aprilie), in ANIC, fund CC al PCR - secția Cancelarie, dossier no. 47/1968, p. 4-6. The original text in Romanian: "în programul vizitei este prevăzută depunerea de către preşedintele Consiliului de Miniştri a unei coroane de flori la Monumentul soldatului necunoscut. Menționăm că, potrivit practicii locale, şefii de state şi guverne care vizitează Finlanda depun coroane de flori atât la Monumentul soldatului necunoscut, cât şi la monumentul lui Mannerheim (erou național al Finlandei), care se află alături. În acelaşi fel a procedat şi preşedintele Tito când a vizitat Finlanda."
} 
In any case, Maurer's gesture caused a great impression in Helsinki and... in Moscow too, for that matter. Maurer and Mănescu met high Finnish officials like the president, prime-minister and minister of foreign affairs and discussed issues of bilateral relations, especially trade and economic cooperation. They visited various cities, industrial and cultural objectives and were interviewed by the Finnish press. Corneliu Mănescu delivered a lecture at the Association of Foreign Policy in Helsinki, which was highly appreciated by the audience ${ }^{33}$. In the end of the visit, both Romanian officials met a delegation of the Finnish Communist Party and held talks. President Kekkonen accepted the invitation to visit Romania which he was going to honour next year. Maurer's visit in Helsinki was, in the end, a great success, from all points of view and marked a new step in Romanian-Finnish relations ${ }^{34}$.

Similar progress was reached in relation to Sweden as well. After Helsinki, Maurer and Mănescu visited Stockholm for a few days, in response to an official invitation from the Swedish government. As Romania was intensely looking for commercial partners outside CMEA and Sweden was a neutral country, economic relations between the two countries had developed a lot in the past years and Sweden became of Romania's most important commercial partners in the North. Less political restrictions to trade in the Communist bloc combined with high level of technological development made Sweden an ideal partner for Romania. Ceauşescu was interested in maintaining and widening this partnership. This is why Maurer's mission to Stockholm was to improve the basic premises of such a partnership.

From an analysis compiled by the Romanian Ministry of Foreign Affairs and approved by the party leadership, the most important issue in bilateral relations was the trade deficit. Romania's exports to Sweden represented barely over $30 \%$ of its imports, in terms of value. This created a serious payment issue for Romania which could only be could only be solved - on the long run - by increasing Romanian exports in Sweden. Maurer was therefore in charged not only with discussing the possibility of enlarging imports of technological equipment and industrial lines but he was also interested in obtaining promises that the government in Stockholm will take measures to facilitate Romanian exports on the

\footnotetext{
33 ibid.

34 Scânteia, 5 April 1968.

206
} 
Swedish market, especially products of light industry ${ }^{35}$. There were also other problems at stake, like the Romanian debt to Sweden, resulting from the interwar public debt and from the compensation owed to Swedish investors for the nationalized goods and proprieties. The debt had been negotiated, at that point, for more than 15 years with no result, but the prospects for a positive solution were improving at that time, along with a proportional decrease in Swedish claims.

Maurer's visit to Stockholm, although less noisy than the one in Helsinki, was a success as well. The Swedish government always tried to dissociate topics and a visit meant to contribute to improving relations and identifying new opportunities for cooperation was not used to bring forth controversial issues of the past, so the negotiations of the public debt were left for the specialists, behind the curtain. There was also a large degree of interest from Swedish investor and businessmen too, because in the past few years Romania had gained a positive reputation on Western markets for being always interested to buy and paying honestly. It looked rather safe to do business with Romania.

The Romanian delegation was welcomed with warmth and interest in Stockholm. The program of the visit was just as consistent as the one in Helsinki, including meeting with various governmental officials, businessmen, visits to industrial and cultural objectives. Meeting representatives of Swedish industry, Maurer spoke with optimism about Romania's plans for the futures and its perspectives for industrial development ${ }^{36}$. Politically, he invited his homologous, premier Tage Erlander, to visit Romania some time next year and his invitation was accepted. Economically, the visit opened the way for new commercial and industrial opportunities, as did the visit in Finland, so from this point of view, it was another success that Romania marked on the eve of the Soviet intervention in Czechoslovakia ${ }^{37}$. The international visibility and prestige of the country were increasing through such visits and the partnerships

\footnotetext{
35 Notă de propuneri referitor: directive privind vizita în Suedia a preşedintelui Consiliului de Miniştri, Ion Gheorghe Maurer, şi a ministrului afacerilor externe, Corneliu Mănescu (8 - 11 aprilie), in ANIC, fund CC al PCR - secția Cancelarie, dossier no. 47/1968, 10-13

36 ibid., 15

37 Scânteia, 11 April 1968. Concerning the personality and political relevance of premier tage erlander, see: Olaf Ruin, Tage Erlander: Serving the Welfare State, 1946-1969 (University of Pittsburgh Press, 1990)
} 
established reduced Romania's dependence on Soviet resources and exchanges within CMEA.

Swedish primer Tage Erlander visited Romania in April 1969, accompanied by Foreign Minister Torsten Nilsson. Erlander and Nilsson met Nicolae Ceauşescu who invited them for dinner, discussing generalities concerning bilateral relations and the international situation. Erlander also held talks with Maurer regarding the progress achieved in economic cooperation since the last meeting and prospects for enlarging trade in the future ${ }^{38}$. Such meetings had a very important role in mutual knowledge and Tage Erlander had a very good time in Romania. Before arrival, he expressed the wish to visit some of the monasteries in Northern Moldova and the host responded promptly. The program of his short visit included a visit to Monastery Neamt, but also to the Museum of Art in Bucharest, given the guest's taste for culture. At departure, Erlander and Nilsson expressed their belief that Romanian-Swedish relations can and must improve even more in the future and that the government they represent is committed to do everything to help that 39 .

In the summer of $1969 \mathrm{~N}$. Ceauşescu was very busy to organize the $10^{\text {th }}$ Party Congress and welcome US President Richard Nixon to Bucharest. Romania was the first country ever to be visited by an American President and that put N. Ceauşescu on the front page of all international newspapers. He even had to delay Brezhnev's visit to Bucharest for that, which caused great distress in Romanian-Soviet relations. When things cooled down in early fall, Ceauşescu welcomed another guest in Bucharest, not so powerful but just as important in what concerned Romania's foreign and commercial policy. President of Finland Urho Kekkonen arrived in Bucharest at premier Maurer's invitation in September 1969 and received a greeting just as warm as that which Maurer enjoyed in Helsinki one year before.

Needless to say that for both parts the most important purpose of the visit economic cooperation. Romanian-Finish commercial exchanges in the previous five years had not exceeded 2-3 million US dollars for imports and approximately the same for exports, with a slight deficit for Romania.

\footnotetext{
38 Notă de propuneri referitor: programul vizitei oficiale în Republica Socialistă România a primului ministru al Suediei, Tage Erlander, cu sotia (11 - 15 aprilie 1969), in ANIC, fund CC al PCR sectia Cancelarie, dossier no. 34/1969, 73-75

39 Scânteia, 16 April 1968

208
} 
Both countries were strongly interested in increasing the volume of mutual trade. Romania was selling oil and oil products, chemicals, agricultural products and timber to Finland and was interested in enlarging its exports with new products such as tools and machineries. Imports from Finland consisted mainly in staple fiber, cellulose, paper and carton ${ }^{40}$. Still, both Romania and Finland had sufficient common interests in foreign policy as to look at each other with sympathy, especially after the successful getting through with the UN Resolution. So Ceauşescu and Kekkonen met each other with curiosity and interest on 23 September 196941.

The discussions focused around international policy issues. Kekkonen reaffirmed his country's commitment to neutrality as well as its determination to pursue a friendly policy towards the USSR. He was interested to know Ceauşescu's position regarding the crisis in the Middle East. Ceauşescu spoke about Romania's foreign policy and its limitations deriving from the WTO membership. Although Romania was militating for a simultaneous dismantling of both NATO and WTO, until such a situation will occur Romania was obliged to remain aligned, as a guarantee of its own security. But that was not closing all options of foreign policy, as Ceauşescu was explaining Kekkonen, because Romania felt there was space enough to increase it say in international matters and its alignment did not involve a renunciation to its sovereign right to speak for itself and to decide for itself. From this point of view, the Romanian leader pointed out, it was very important for small states to become more active on the international scene, in order to compensate the heavy pressure exerted by the Great Powers ${ }^{42}$.

In Ceauşescu's opinion, real security could only be attained by involving all states, not just the Great Powers: "we reached the conclusion that the times when the Great imperialistic Powers imposed their point of view disregarding other states' interests have passed and it seems that many peoples reached this conclusion in what concerns small and medium nations and even some

\footnotetext{
40 Notă referitor: stadiul relațiilor bilaterale româno-finlandeze, in ANIC, fund CC al PCR - secția Relații Externe, dossier no. 52/1969, 95-96

41 Programul vizitei oficiale în Republica Socialsită România a Excelenței Sale Domnului Urho Kekkonen, Preşedintele Republicii Finlanda, in ANIC, fund CC al PCR - secția Relații Externe, dossier no. 52/1969, 22

42 Stenograma discutiilor purtate de Nicolae Ceauşescu, preşedintele Consiliului de Stat al RS România, cu Urho Kekkonen, preşedintele Republicii Finlanda (23 septembrie 1969), in ANIC, fund CC al PCR - secția Relații Externe, dossier no. 52/1969, 5-6
} 
of the big states began to understand that the old model to impose domination does not correspond to today's conditions. From this general judgments commences Romania's international position and this is why we reached the conclusion that it's necessary to conduct an active policy to develop relations with all states (...)." 43 Ceauşescu also explained Kekkonen Romania's position regarding the Vietnam War, where he blamed everything on the Americans and even bragged to have said that even to Nixon when he was in Bucharest. He also spoke about how important it was for Romania the issue of European security and the possibility of a common European agreement on security and cooperation ${ }^{44}$.

Kekkonen concluded that both parts had similar or identical points of view in mostly all international issues, including Vietnam, Israel, European security or even China's representation in the United Nations. In what concerned bilateral relations, Ceauşescu and Kekkonen agreed that it was necessary to in charge the governments with the task of identifying new ways of enlarging cooperation because it was well below the possibilities, especially the trade ${ }^{45}$. That was how discussions ended and the Kekkonen continued his visit in Romania with a trip in the Danube Delta to which he had been looking forward since is arrival.

Erlander and Kekkonen's visits to Romania marked a step forwards in Romania's relations with the Nordic countries. From the Swedish or Finnish points of view, improving relations with Romania was advisable and necessary due to foreign policy convergences, mainly after Romania began pursuing an independent and active course in the Communist bloc, but also - and foremost - because it offered new economic opportunities, both as a market and a provider of resources. For Romania, on the other hand, it was another success of the Western oriented policy. Its basic aim, that identifying partners in other areas except from the Communist bloc in order to reduce Soviet pressures, was reached in what concerned Scandinavia. These two visits used a gate opened before in order to bring relations to the next level. It was a qualitative change that became relevant in the following years, when bilateral trade continued to increase significantly.

\footnotetext{
43 ibid., 7

44 ibid., 10

45 ibid., 19

210
} 
So what is the common denominator in the end? It cannot be limited to one single factor but two are worthy to be pointed out with emphasis: economic interest and small states affirmation in a bipolar world. On a stage dominated by Great Powers, three small states found a way to overcome mistrust, political divisions and other larger stakes that the Great Powers were imposing on everybody's shoulders and made a choice to pursue their own national interest. Such small steps which can easily be described by the UN Resolution mentioned at the beginning of this paper played an essential role in preparing the European Conference on Security and Cooperation and also in ending the Cold War.

\section{References:}

\section{A. Archives:}

Arhivele Naționale Istorice Centrale [National Historical Archives of Romania], fund CC al PCR, section Chancellery, dossiers nos. 19/1966, 128/1966, 48/1967, 47/1968, 34/1969.

Arhivele Naționale Istorice Centrale, section External Relations, dossiers nos. 8/1967, 52/1969

\section{B. Published documents, newspapers and statistics:}

Annual Report of the Secretary-General on the Work of the Organization. United Nations, 1965

Scânteia, 1968

C. Memoirs:

Malița, Mircea. Tablouri din războiul rece. Memorii ale unui diplomat român. Bucureşti: Editura C.H. Beck, 2007

\section{Books and articles:}

Andrén, Nils. Power-balance and non-alignment: a perspective on Swedish foreign policy. Almqvist \& Wiksell, 1967

Bajpai, U.S. Non-alignment, perspectives and prospects. Lancers Publishers, 1983

van Brabant, Jozef M. Socialist economic integration: aspects of contemporary economic problems in Eastern Europe. Cambridge University Press, 1980

Browning, Christopher S. Constructivism, Narrative and Foreign Policy Analysis: A Case Study of Finland. Peter Lang, 2008 
Cătănuş, Dan. „Impactul raportului „secret” asupra conducerii PMR. Destalinizarea în România". Dan Cătănuş, Vasile Buga, eds., Lagărul comunist sub impactul destalinizării. 1956. Bucureşti: Institutul Național pentru Studiul Totalitarismului, 2006

Forst, Robert. "Nicolae Ceauşescu, the «Great Genius of the Carpathians». Bernd Jürgen Fischer, ed., Balkan strongmen: dictators and authoritarian rulers of South Eastern Europe. Purdue University Press, 2007

Hadenius, Stig. Swedish politics during the 20th century: conflict and consensus. Svenska institutet, 1997

Hey, Jeanne A. K. Small states in world politics: explaining foreign policy behavior. Lynne Rienner Publishers, 2003

Kramer, Mark. „The Early Post-Stalin Succession Struggle and Upheavals in East-Central Europe. Internal and External Linkages in Soviet Policy Making (Part I)". Journal of Cold War Studies, vol. I, nr. 1(1999)

Korhonen, Keijo. Urho Kekkonen: a statesman for peace. Otava, 1975

Leatherman, Janie. From Cold War to democratic peace: third parties, peaceful change, and the OSCE. New York: Syracuse University Press, 2003

Miloiu, Silviu, O istorie a Europei nordice şi baltice, vol. II De la războiul rece la era globalizării. Târgovişte: Editura Cetatea de Scaun, 2005

Petrescu, Dragoş. „Legitimacy, Nation-Building and Closure: Meanings and Consequences of the Romanian August of 1968". M. Mark Stolarik, ed., The Prague Spring and the Warsaw Pact Invasion of Czechoslovakia, 1968. Bolchazy-Carducci Publishers, 2010

Rainer, János. The New Course in Hungary in 1953. Working Paper nr. 38. Washington DC: Woodrow Wilson International Center for Scholars, 2002

Ruin, Olaf. Tage Erlander: Serving the Welfare State, 1946-1969. University of Pittsburgh Press, 1990

Solem, Erik. The Nordic Council and Scandinavian integration. Praeger Publishers, 1977

Stanciu, Cezar. "Scandinavian Perspectives. Overcoming the Cold War pressures in Romania's policy towards Northern Europe". Revista Română de Studii Nordice şi Baltice, no. 1 (2009)

Tismăneanu, Vladimir. Stalinism for all seasons: a political history of Romanian communism. University of California Press, 2003

Väyrynen, Raimo. Stability and change in Finnish foreign policy. Helsinki: Helsingin yliopiston, 1986

Zwass, Adam. The Council for Mutual Economic Assistance: the thorny path from political to economic integration. M.E. Sharpe, 1989 